\title{
Development of Learning Materials PR Script Writing Shaped Flip Book
}

\author{
Fifit Fitriansyah $^{1}$, Hartati Muchtar ${ }^{2}$, Diana Nomida Musnir ${ }^{3}$ \\ \{fitriansyah.fifit87@gmail.com ${ }^{1}$, hartatimuchtar@yahoo.com ${ }^{2}$, diananomida2019@gmail.com ${ }^{3}$ \} \\ Universitas Negeri Jakarta, Indonesia
}

\begin{abstract}
The ability of lecturers in developing learning materials influences the success of the learning process, especially vendors of materials with an attractive look such as a flip book or ebook. This research aims to develop the learning materials of PR script writing in the form of ebook or flip book for students majoring Public Relations of UBSI. The development of learning materials used Dick and Carey model with Research and Development Approach of Borg and Gall which consists of 10 development stages modified by researcher. The result of this research is a textbook of PR script writing in the form of flip book (ebook). The learning result of students using flip book PR script writing as the learning materials increased by $93 \%$ compared to students who did not use The flip book PR script writing as much as $54 \%$.
\end{abstract}

Keywords : Development, Learning Materials, Flip Book

\section{Introduction}

Some people who had known the tradition of writing and reading, making both as a very important activity.This is not because the information is received by someone occasionally delivered not only verbally, but also writing.Public relations Writing technique itself is typical of the writing skills of public relations/PR in producing texts that are required in order to build up a positive image and popularity of a company or organization.One of the PR script which was popular among the mass media is a media kit (press kit).Media Kit (press kit) in the form of written materials such as backgrounders, press releases, advertorials and brochures containing comprehensive information about the activities of the objectives, schedule, target objectives, the structure of the Committee, the list of invited artists, and so on, then put it in a folder or large envelope. Therefore, the press circles have accurate and complete data as material related news of the company or organization.

Based on the review of the field obtained by researchers, which occurs when it is still a low level of writing ability on the part of the public relation practitioners. It is because of the education practitioners backgrounds that are not derived from the Communication Study Program with public relations concentration. Various data were found by the researcher. Many practitioners who have the educational background of management, marketing, economics and accounting that is certainly in its activities less emphasis on writing as a mandatory competency.

PR script writing course is one of the flagship courses for students of Public Relation Study Program of Bina Sarana Informatika University which introduces and provides knowledge of the skills that should be possessed by a public relation officer, in this case is 
writing skill. His goal after studying scriptwriting techniques of public relation, are students able to generate media kit in the form of PR script that can be used as tools in the exercise of his profession. The existence of the development of learning materials in the form of PR script writing media flip book makes learning becomes more attractive, effective and easy, where students can read by using mobile phone or computer so that they can study independently.

Learning materials are a set of tools or means of learning which includes learning materials, methods, limitations as well as how to evaluate systematically designed and attractive in order to achieve the expected goal that is achieved basic competencies. [1] The materials generally are often referred to as a subject matter in other words as a some sort of knowledge is systematically composed of units subject matter, so that materials can be said as a tool and medium gives the opportunity to students to acquire a learning experience.[2]

In doing, learning materials also need to be structured to be one reference that will support the development of students so that there is a balance between the physical and spiritual needs.For materials as a learning tool that is included with one of the dynamic elements in learning, so the position of the tool has an important role because it can help the learning process of students.[3]

Learning materials can be divided into several types: (1) learning materials perspective (visual) consists of printed materials (printed) such as, among others, handouts, books, student worksheets, module, brochure, leaflet, wallchart, photos/images, and non-print (non printed), like model/scale model; (2) materials (audio) listen as cassettes, radios, LPs, and audio compact disk; (3) the materials point of view heard of (audio-visual) such as video compact disks, movies; (4) interactive multimedia learning materials (interactive teaching material) as CAI (Computer Assisted Instruction), compact disk (CD) multimedia interactive learning, and web-based materials (web based learning materials).[4]

The PR script writing materials were made not only in print, but also a paperless/ebook that was applied using a flip book.Definition of ebook itself is a book in digital form either a file with a .pdf extension which can be read via a computer or mobile phone by using the software adobe acrobat reader.[5] According to Hurtado, said that flip book is considered one of the earliest forms of interactive media. A (in capital letter) flip book consists of a series static pictures that change only slightly from page to page by holding the book in one hand.[6] Thus, the flip book is a series of images in a digital book that seems to move if its pages were reversed quickly. Starts at the stage of analysis of the need to develop and to select instructional materials after the materials are selected, then the next is designing the look of learning materials in the form of a flip book or ebook.Learning materials developed in the form of flip book software made by using PDF Flip Professional or Flip Builder.

\section{Methodology}

The research method used is the research and development or known as the research and development (R\&D adopting the model of the development of the Borg and Gall, i.e. the research methods used to produce a particular product and test the effectiveness of a product.[7] Products produced in this research is the PR script writing materials that come with the kit, making media guide in the form of flip book. In developing the PR script writing materials in the form of flip book, the researchers used a model of the development of the Borg and Gall that has ten stages of development which was later formulated into ten stages in this study that GSL sports developers as it can be described in the following: 1) preliminary 
studies; 2) planning; 3) drafts design products; 4) product development; 5) formative evaluation and designing; 6) evaluation by expert judgement; 7) evaluation of one to one person; 8) evaluation of small group; 9) evaluation of field test; 10) final product. [8] The research dataset can be accessed in https://osf.io/v37e2/ Open Science Framework in title of he Design of The Development Model of The Borg And Gall, and the data are presented in Bahasa Indonesia[9].

The instruments of data collection in this research is assessment scale values. As for the instruments used indicators refers to an instrument development instructional design according to Suparman Atwi consisting of needs analysis, instructional analysis, instructional Objectives, formative evaluation instruments, strategies learning, the creation of learning materials.[10] Data collection techniques used in obtaining data regarding the implementation and the effectiveness of the model is done by means of: 1) Guidelines for observation; 2) Interview guidelines; and 3) question form. The research dataset can be accessed in https://osf.io/v37e2/ Open Science Framework in title of Data Collection Techniques, and the data are presented in Bahasa Indonesia[9]. The analysis of the data used is descriptive qualitative i.e. analyzing data by way of describing or depicting the various characteristics of the data that has been accumulated with as-is without any mean to give a conclusion in general or generalization.[7] Calculating an average score of data used in each component using the following formula Total average score indicator divided by the number of problem, then find the average score of the aspects/components.[11] The research dataset can be accessed in https://osf.io/v37e2/ Open Science Framework in title of Data Processing Formula, and the data are presented in Bahasa Indonesia[9]

The effectiveness of the models can be seen through the results of the study in the form of performent assessment using rubrics assessment The research dataset can be accessed in https://osf.io/v37e2/ in title of rubrics assessment which is presented in Bahasa Indonesia [9]. Performance assessment can provide an overview of the capabilities of the learners as a whole so that the successful implementation of performance assessment is closely related to the design of a good judgment, for it educators need to develop performance assessment of learning needs.[12] Data analysis technique used is the total score of the average number of indicators divided by the number of problem. The research dataset can be accessed in https://osf.io/v37e2/ Open Science Framework in title of Data Processing Formula, and the data are presented in Bahasa Indonesia [9]. In analyzing the data above, first formulated in quantitative data which is then described being qualitative data by looking at the average percentage of assessments.

\section{Results and Discussion}

The result of the development of this model is a form of PR script writing materials in the form of a textbook which comes with a guide to make media kit.This textbook is made in the form of eBooks by using PDF Flip Professional or PDF Builder software.With turned textbook in the form of flip book, then facilitate students in reading the textbook, since it can be read via a computer or mobile phone.In addition, the textbook in the form of flip book also makes the learning materials into a more interactive, engaging and efficient.

In the process of development, researchers also refer to the process steps of the learning model development Dick and Carey are combined by step development Atwi Suparman in the model of MPI researcher who later modifications, while for the learning materials 
development researchers use model Borg and Gall it self. The research dataset can be accessed in https://osf.io/v37e2/ Open Science Framework in title of Design Development Learning, and the data are presented in Bahasa Indonesia [9] The selection of the model of development of the Dick and Carey model which is the development of learning with the simplest approach system assessed so judged efficient compared to other development models.A learning model of development Dick and Carey has also been used by many researchers as a model of research and development. Script writing PR materials developed very cared for instructional materials, where it needs to be designed as complete as possible so that students can use them appropriately and easy to understand, to understand the objectives that will be achieved in the learning, get the script writing examples of public relations that correspond to the standards of the PR script writing, to be able to measure results close to learning through formative tests are given on each of his encounters. Following is the display of the PR script writing materials in the form of a flip book as the end product of this development:

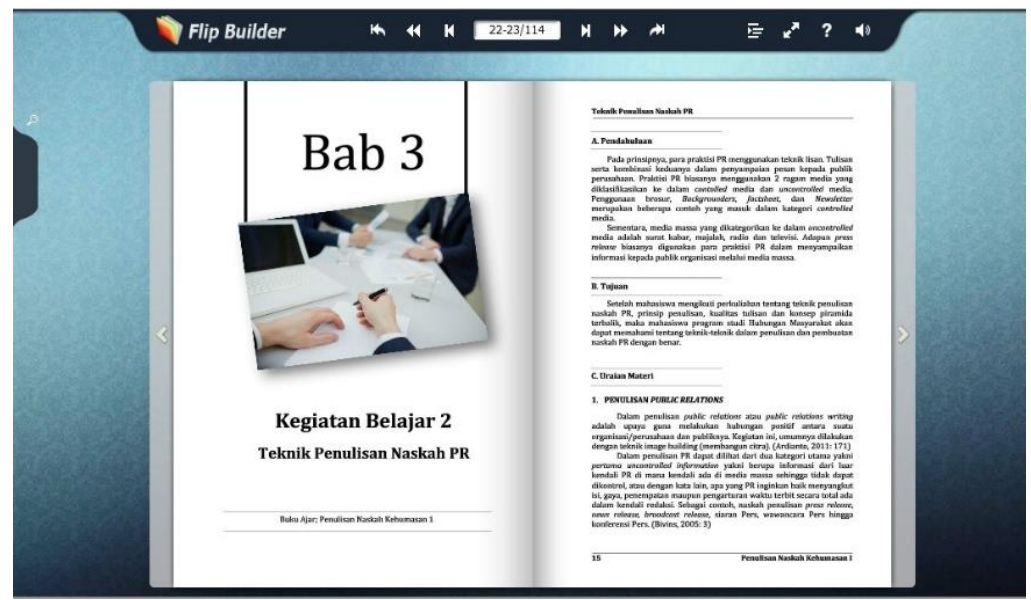

Fig. 1. Display product PR script writing materials in the form of flip book. The research dataset can be accessed in https://osf.io/v37e2/ in title of Flipbook PNK[9]

Based on the results of the assessment on the empirical testing has been done on the expert instructional design experts, material, linguist and expert on media then advice and input as materials improvement on product learning materials shaped a flip book.After the repair is done and then tested again on a one to one person, small group and filed (The research dataset can be accessed in https://osf.io/v37e2 in title of Test Documentation [9]) their respective test advice and input as materials improvement product, for that matter, overall a ssessment of the empirical shows that learning package developed products are qualified both the empirical and teoritik to be implemented or used in the actual field, i.e. in class in script writing learning PR.

In an attempt to find out the effectiveness of improved models i.e. in the form of improved quality of learning outcomes learning students, then the developers tested the effectiveness of the package pembejaran PNK in 2 different classes.On class A as many as 25 students were given the learning package PNK, while for contrast, developers are testing the effectiveness of class B products totalling 25 students (according to the number of students in the class) as a group who do not given the learning package.It is intended to see how much the effectiveness of the learning package PNK developed in the improved quality of learning 
outcomes. The effectiveness of this test is given at 4 times the meeting in accordance with the number of meetings on a charged material works (making the product media kit), and test the effectiveness is evaluated using a rubric assessment used by each lecturer class. The use of self-assessment rubric because subjects are works in which students create media kits are then presented. As for the results of the rubric assessment on the effectiveness of the learning package PNK can look at a picture of the chart below:

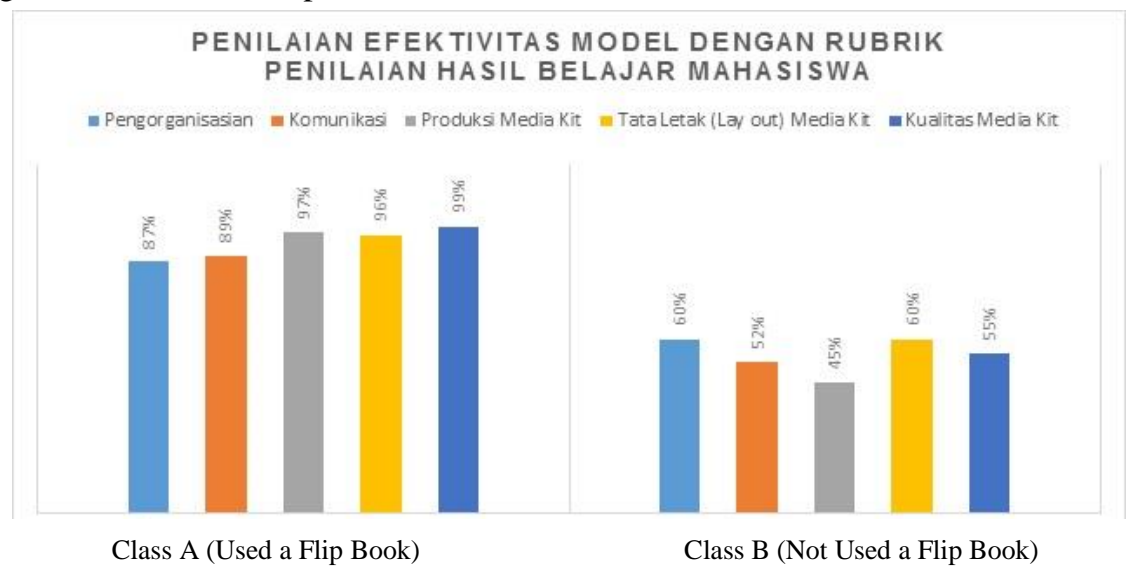

Fig. 2. The Effectiveness of The Model With The Student Learning Outcomes Assessment Rubric

Based on the assessment table is retrieved by using the rubric assessment of the quality of student learning outcomes, then it can be explained that the degree of success of learning on grade i.e. that use materials script writing PR in the form of flip book higher i.e. as much as $94 \%$ while class B that do not use PR script writing materials in the form of a flip book as much as $54 \%$ there is a difference between $40 \%$ against the learning outcomes obtained by students.Thus, this indicates that the quality of the PR script writing materials developed have a high effectiveness compared to classes that do not use.

\section{Conclusion}

The result of the development of learning materials to this PR script writing has an important influence in improving learning outcomes, the PR script writing for it, in the process the required synergy between the lecturers courses and students.With the PR script writing materials in the form of flip book, students can study independently and repeatedly, while for lecturers assist in delivering learning materials.With the use of manuscript writing PR materials in the form of flip book, learning becomes more attractive, independent, efficient and interactive. Based on the results of the assessment on empirical trials that have been carried out on material experts, instructional design experts, linguists and media experts, then the suggestions and inputs are used as improvement material in teaching materials products. After repairs are then tested again on one to one person, small group and filed test, each suggestion and input is used as product improvement material, for that reason, overall the empirical assessment shows that the teaching materials developed have met good 
requirements. theoretically and empirically to be implemented or used in the actual field, namely in the class in the learning of Public Relations Script Writing.

\section{Acknowledgement}

In the process of this research, researchers like to thank parents, husband, the beloved, promoter and co-promotor, friends, students also to the research place at AKOM BSI Jakarta. With the support whether material and non-material that had been sent a researcher of the completion of this research. Finally researchers hope that this research can give benefits for science development, readers, as well as the researchers.

\section{References}

[1] C. S. Widodo and Jasmadi STP, Panduan Menyusun Bahan Ajar Berbasis Kompetensi. Jakarta: PT Elex Media Komputindo, 2008.

[2] G. Nurjaya, "Pengembangan Bahan Ajar Metode Pembelajaran Bahasa dan Sastra Indonesia Berbasis Pembelajaran Kooperatif Jigsaw dan Kemampuan Aplikatif Mahasiswa," J. Pendidik. Indones., vol. 1, no. 2, pp. 102-111, 2012.

[3] A. Kusumam, Mukhidin, and B. Hasan, "Pengembangan Bahan Ajar Mata Pelajaran Dasar dan Pengukuran Listrik UntukSekolah Menengah Kejuruan," J. Pendidik. Teknol. dan Kejuru., vol. 23, pp. 28-39, 2016.

[4] D. A. Nugraha, A. Binadja, and Supartono, "Pengembangan Bahan Ajar Reaksi Redoks Bervisi Sets, Berorientasi Konstruktivisme," J. Innov. Sci. Educ., vol. 2, no. 1, pp. 27-34, 2013.

[5] A. Shera, Step by Step Internet Marketing. Jakarta: PT Elex Media Komputindo, 2010.

[6] D. Hurtado, Flipping Out the Art of Flip Book Animation. USA: Walter Foster Publishing, 2016.

[7] Sugiyono, Metode Penelitian Kuantitatif, Kualitatif dan R\&D. Bandung: Alfabeta, 2012.

[8] Borg and Gall, Educational Research an Introduction. New York: Longman, 1983.

[9] F. Fitriansyah, "Dataset Development of Learning Materials PR Script Writing Shaped Flip Book," 2019. [Online]. Available: https://osf.io/v37e2/. [Accessed: 03Jan-2019].

[10] A. Suparman, Panduan Para Pengajar \& Inovator Pendidikan Desain Instruksional Modern. Jakarta: Erlangga, 2012.

[11] A. Suharsimi, Dasar Dasar Evaluasi Pendidikan. Jakarta: Bumi Aksara, 2009.

[12] I. N. Diartha, Wildan, and Muntari, "Penilaian Kinerja (Performance Assessment) Dalam Pembelajaran Kimia,” J. Pijar MIPA, vol. 11, no. 1, pp. 65-69, 2016. 